\title{
Copper Toxicity to Tropical Water Flea Daphnia carinata and Freshwater Micro-algae Scenedesmus
}

\author{
Khoa Dinh Hoang Dang
}

Environmental Biotechnology Laboratory, Institute for Environment and Resources

National University Vietnam, Ho Chi Minh City, Vietnam

E-mail: dhdangkhoa.ier@gmail.com

Thi Thu Hang Pham

Environmental Biotechnology Laboratory, Institute for Environment and Resources

National University Vietnam, Ho Chi Minh City, Vietnam

Ngoc Tu Anh Pham

Environmental Biotechnology Laboratory, Institute for Environment and Resources

National University Vietnam, Ho Chi Minh City, Vietnam

\section{Hien Minh Tam Le}

Environmental Biotechnology Laboratory, Institute for Environment and Resources

National University Vietnam, Ho Chi Minh City, Vietnam

\section{Tran Thi Yen Nhi}

Environmental Biotechnology Laboratory, Institute for Environment and Resources National University Vietnam, Ho Chi Minh City, Vietnam

\author{
Nguyen Thi Thanh Phuong \\ Institute for Environment and Resources \\ National University Vietnam, Ho Chi Minh City, Vietnam
}


Le Phi Nga

Department of Biotechnology, Ho Chi Minh City University of Technology

Vietnam National University HCMC, 268 Ly Thuong Kiet Street

District 10, HCM City, Vietnam

Dinh Hoang Dang Khoa (Corresponding author)

Environmental Biotechnology Laboratory, Institute of Environment and Resources

Linh Trung, Thu Duc District, HCM City, Vietnam

E-mail: dhdangkhoa.ier@gmail.com

Received: August 26, 2020 Accepted: September 20, 2020 Published: X, 2020

doi:10.5296/emsd.v9i4.17539 URL: https://doi.org/10.5296/emsd.v9i4.17539

\begin{abstract}
Sai Gon river is one most the most important river of South-eastern region of Vietnam by providing water resources and others vital natural services for millions of people in this area. In recent years, proportion with the sharply increasing of human activities in industry and agriculture, the river is continuously loaded with xenobiotics released by anthropogenic activities. Among pollutants, heavy metals are considered as the most toxic elements to aquatic living organisms and human health. The aim of this study is to assess the sensibility of freshwater microalgae Scenedesmus and water flea Daphnia carinata, two fresh water species from Vietnam to copper $(\mathrm{Cu})$. After physical and chemical characterization, field water samples from upstream Sai Gon River was used as dilution water in toxicity tests. With water flea $D$. carinata, the EC50 value of $48 \mathrm{~h}$ immobilization experiment was $1.90 \mu \mathrm{g} / \mathrm{L}$. Growth inhibition of the Scenedesmus algae cells was determined following exposure for 72 $\mathrm{h}$, and EC50 values was $78.2 \mu \mathrm{g} / \mathrm{L}$. The results showed that $\mathrm{Cu}$ is highly toxic to both species, and water flea $D$. carinata was more sensitive than freshwater algae Scenedesmus. Based on the observed high sensitivity with $\mathrm{Cu}$, both $D$. carinata and algae Scenedesmus are potential tools for the assessment of copper pollution in fresh water of Sai Gon river.
\end{abstract}

Keywords: Acute toxicity, Daphnia, Algae, Freshwater, Copper, Sai Gon river

\title{
1. Introduction
}

In Vietnam, fresh surface water pollution and deterioration has been an important problem because of its impact on human health and aquatic ecosystem. However, monitoring of fresh water quality are limited due to the shortage of human and financial resources. In recent years, the quickly induction of urbanization and industrialization become main reasons of increasing 
water demands, and water pollution caused by anthropogenic activity. Therefore, it called for a better procedure to monitor the quality of water in Sai Gon river system, which are important water resources for Ho Chi Minh, the biggest city in Southern of Vietnam. Among variety of contaminants which can pollute the fresh water and toxic to human health, heavy metals are great concern due to its toxicity and persistence once introduced into the aquatic environment (Beiramzadeh et al., 2019; Saberi et al., 2018). The objective of this study was to investigate the possibility of using tropical fresh water living creatures to detect the contaminated $\mathrm{Cu}$ in the water due to its toxicity. This study is going to contribute to provide a simple and cost effective method to quickly assess the toxicity of fresh water quality, to protect the water resource and health of water users.

Metals are among the most intensively studied pollutants in fresh water environments. Many of metals are important for living processes at very low concentrations, but at higher doses they become toxic (Warnau et al., 1995). Metals can be introduced into environment from many anthropogenic activities such as industrial, agricultural, and mining processes, then they become tolerant pollutants and pose significant risks on living creatures in the ecosystem including (Lanctôt et al., 2016; Schwarzenbach et al., 2010; Tomasiks \& Warren, 1996). While some metals play vital roles in living processes of organisms, some others do not. On another hand, it is worth to note all metals become toxicants while reach a concentration threshold (Wetzel, 2001). The previous studies have pointed out that metals are indestructible and can be accumulated in body of organisms (Lau et al., 1998; Waykar \& Shinde, 2011), then transferred to higher trophic levels of the food chain (Ikemoto et al., 2008). The toxic effects of metals to living organisms have been well defined and considered as a major threat to aquatic biodiversity (Millennium Ecosystem Assessment, 2005; Dinh Van et al., 2013; Lanctôt et al., 2016; Moldovan et al., 2013). Also, it has been found that toxicity of dissolved metals in water is regulated by variety of water physical and chemical characteristics such as $\mathrm{pH}$, alkalinity, dissolved organic carbon (DOC) and hardness (De Schamphelaere \& Janssen, 2004; Hoang et al., 2004; Jo et al., 2010; Linbo et al., 2009; Ryan et al., 2009). Therefore, it is essential that the living organisms used in toxicity detection test must be sensitive to the suspected metal - copper in context of Sai Gon river's water characteristics. In this study, the water sample was collected from the upstream of Sai Gon river, and used as dilution water in the toxicity test to define the sensitivity level of tropical $D$. carinata and algae Scenedesmus.

The experimental sensitivity to $\mathrm{Cu}$ of the two tropical freshwater organisms obtained through this study can serve as starting point for developing a cost-effective pollution monitoring procedure. The two living organisms were chosen due to high sensitivity of micro-crustacean Daphnia to dissolved heavy metals in water, while planktonic algae are easy to culture, and require only small laboratory space and simple equipment. Algae are primary producers of which population growth inhibition can be used as criterion of response in toxicity test. Moreover, the inhibition of algae's population in aquatic environment can imply the chain reaction on ecological food chains in water environment.

The purpose of this study is to develop and optimize a procedure using a battery of organisms for use in routine monitoring of freshwater of Sai Gon river. One of the first criteria for toxicity test is sensitivity of organism to contaminant of interest. Therefore, we aim to 


\section{Al Macrothink}

develop a practical process which enable to detect $\mathrm{Cu}$ pollution in fresh water using a battery of organisms. The test battery consists of two species representatives of two consecutive trophic levels: micro algae Scenedesmus sp. (primary producer), and D. carinata (primary consumer).

\section{Materials and Methods}

\subsection{Water Samples Collection}

Surface water was collected from the upstream of Sai Gon river (Dau Tieng freshwater reservoir). The water sample was transferred to the Environmental Toxicology Laboratory, Institute for Environment and Resources in Hochiminh City, filtered through $0.45 \mu \mathrm{m}$ syringe filter (Sartorius, Germany) and stored at $4{ }^{\circ} \mathrm{C}$ prior to the tests.

\subsubsection{Water Samples Characteristics}

The filtered waters from Dau Tieng reservoir was analyzed for water quality parameters that may affect the bioavailability of dissolved metals and the survival and growth of the two organism of test battery, alkalinity and hardness, $\mathrm{pH}$, trace metals and pesticides. Total hardness was determined based on concentrations of $\mathrm{Ca}^{2+}$ and $\mathrm{Mg}^{2+}$, metals were analysis by ICP/MS.

\subsubsection{Test Organisms}

Organisms used in the present study were D. carinata and freshwater algae Scenedesmus sp. These species were collected from the field in Vietnam and have been cultured in the Ecotoxicology Laboratory, Institute for Environment and Resources, Vietnam National University - Hochiminh City for over a year. D. carinata were cultured in $1.2 \mathrm{~L}$ beakers with 1.0 L of COMBO medium (Kilham et al., 1998). The light intensity was approximately 1000 lux. The crustaceans were fed with a mixture of green alga (Chlorella sp.) and YCT (yeast, cerrophyl and trout chow digestion), prepared according to the U.S. Environmental Protection Agency Method (US EPA, 2002) with a modification to the algal culture medium, which was the COMBO medium. Algae Scenedesmus sp. were culture in COMBO medium.

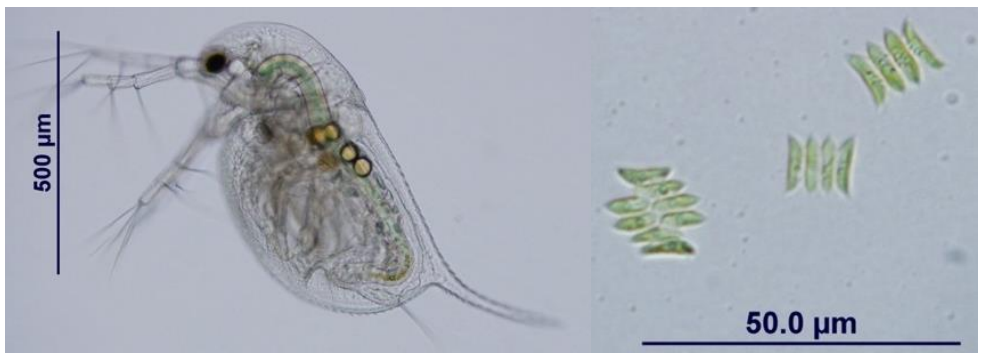

Figure 1. Morphology of D. carinata (neonate) and algae Scenedesmus sp. used in this study

\subsubsection{Acute Toxicity Tests}

The 48-h static nonrenewal acute toxicity tests were conducted following the guidelines of the US EPA methods (US EPA, 2002) with two adjustments of: i) light regime (a photoperiod 
of $12 \mathrm{~h}: 12 \mathrm{~h}$ light: dark at a light intensity of ca. $1000 \mathrm{Lux})$ and ii) temperature $\left(27 \pm 1{ }^{\circ} \mathrm{C}\right)$ for tropical species. Neonates of $D$. carinata (age $\leq 24 \mathrm{~h}$ ) were used for testing. Each treatment had four replicates and each replicate consists of 10 neonates in $40 \mathrm{~mL}$ of exposure solution in a 50-mL polypropylene cup. The neonates were fed during the pre-exposure duration but starved during the tests (US EPA, 2002). Copper treatments were prepared by spiking $\mathrm{Cu}$ in constituted medium prepared with field-collected water. $\mathrm{CuSO}_{4} .5 \mathrm{H}_{2} \mathrm{O}$ was used as $\mathrm{Cu}$ salt. Five concentrations of $\mathrm{Cu}$ were prepared for each metal exposure. Controls were prepared by transferring the neonates into the constituted medium without metal addition.

We checked daily for immobilized organisms and removed them from the cups. Immobilization data were used to determine median lethal concentrations (48 h-EC50). At the end of the test, test solution in one of the four replicates was randomly taken (in each metal concentration) for the metal analysis by ICP/MS.

\subsubsection{Algal Inhibition Test}

Bioassays were performed using the green algae Scenedesmus sp. To analyze the toxic effect of $\mathrm{Cu}$ on the algal growth, serial concentrations of $\mathrm{CuSO}_{4} .5 \mathrm{H}_{2} 0$ were tested using the COMBO media prepared without EDTA (Kilham et al., 1998). The initial inoculum cell density was $2 \pm 0.210^{4}$ cells $/ \mathrm{mL}$, and the assays were performed in triplicate using $125 \mathrm{~mL}$ flasks containing $25 \mathrm{~mL}$ of medium. Cultures were incubated at $24^{\circ} \mathrm{C}$ in constant light $(4000$ Lux), and the algal growth was estimated by absorbance readings at $750 \mathrm{~nm}$ after $96 \mathrm{~h}$ incubation. The effective concentrations of metal inducing 50\% effect (EC50) were calculated by plotting the values for the percent inhibition in average specific growth rate against the logarithmic value of the test substance concentration. Using the regression equation, etc., determine the $50 \%$ inhibition concentration (EC50).

\section{Results \& Discussion}

The aim of this study is to develop a practical and cost effective procedure to detect copper contamination in freshwater of Sai Gon river. The two organisms were selected due to they originated from tropical freshwater environment and therefore easy to use in Vietnam environmental condition.

In order to evaluate the applicable of the procedure in detection the introducing of $\mathrm{Cu}$ into freshwater of Sai Gon river, field water sample was obtained, and spiked with $\mathrm{Cu}$ at different concentration, then put in our toxicity test procedure with a battery of two organisms to detect $\mathrm{Cu}$ contamination. The chemical analyzes result of freshwater from upstream of Sai Gon river showed good quality, without metals or herbicides contamination (table 1). 


\section{Macrothink}

Environmental Management and Sustainable Development

ISSN 2164-7682

2020, Vol. 9, No. 4

Table 1. Dissolved metal concentrations $(\mu \mathrm{g} / \mathrm{L})$ and physical characteristics of filtered field water from Saigon River used for the test. BDL, below detection limits of the ICP/MS. N/A, not available

\begin{tabular}{|c|c|c|c|c|c|}
\hline $\mathrm{Nr}$. & Parameter & Value & Nr. & Parameter & Value \\
\hline 1 & $\mathrm{TSS}(\mathrm{mg} / \mathrm{L})$ & 5 & 17 & $\mathrm{Cd}(\mathrm{mg} / \mathrm{L})$ & $\mathrm{BDL}(\mathrm{LOD}=0.00004)$ \\
\hline 2 & Hardness $\left(\mathrm{mg} \mathrm{CaCO}_{3} / \mathrm{L}\right)$ & 14 & 18 & $\mathrm{~Pb}(\mathrm{mg} / \mathrm{L})$ & 0.0032 \\
\hline 3 & $\mathrm{COD}\left(\mathrm{mgO}_{2} / \mathrm{L}\right)$ & 7 & 19 & $\mathrm{Cr}(\mathrm{mg} / \mathrm{L})$ & 0.006 \\
\hline 4 & $\mathrm{~N}-\mathrm{NH} 4^{+}(\mathrm{mg} / \mathrm{L})$ & $\mathrm{BDL}(\mathrm{LOD}=0.03)$ & 20 & $\mathrm{Cu}(\mathrm{mg} / \mathrm{L})$ & 0.09 \\
\hline 5 & $\mathrm{Cl}^{-}(\mathrm{mg} / \mathrm{L})$ & 4.1 & 21 & $\mathrm{Ni}(\mathrm{mg} / \mathrm{L})$ & $\mathrm{BDL}(\mathrm{LOD}=0.004)$ \\
\hline 6 & N-NO3- (mg/L) & 0.24 & 22 & $\mathrm{Mn}(\mathrm{mg} / \mathrm{L})$ & 0.01 \\
\hline 7 & $\mathrm{P}-\mathrm{PO} 4^{3-}(\mathrm{mg} / \mathrm{L})$ & $\mathrm{BDL}(\mathrm{LOD}=0.01)$ & 23 & $\mathrm{Hg}(\mathrm{mg} / \mathrm{L})$ & $\mathrm{BDL}(\mathrm{LOD}=0.0003)$ \\
\hline 8 & Total N (mg/L) & $\operatorname{BDL}(\mathrm{LOD}=1)$ & 24 & $\mathrm{Se}(\mathrm{mg} / \mathrm{L})$ & $\mathrm{BDL}(\mathrm{LOD}=0.006)$ \\
\hline 9 & Total P (mg/L) & 0.02 & 25 & $\mathrm{Ag}(\mathrm{mg} / \mathrm{L})$ & $\mathrm{BDL}(\mathrm{LOD}=0.003)$ \\
\hline 10 & $\mathrm{SO}_{4}{ }^{2-}(\mathrm{mg} / \mathrm{L})$ & 2.17 & 26 & Lindan $(\mu \mathrm{g} / \mathrm{L})$ & $\operatorname{BDL}(\mathrm{LOD}=0.006)$ \\
\hline 11 & $\mathrm{Al}(\mathrm{mg} / \mathrm{L})$ & 3.34 & 27 & Aldrin $(\mu \mathrm{g} / \mathrm{L})$ & $\mathrm{BDL}(\mathrm{LOD}=0.01)$ \\
\hline 12 & $\mathrm{Ca}(\mathrm{mg} / \mathrm{L})$ & 9.91 & 28 & Dieldrine $(\mu \mathrm{g} / \mathrm{L})$ & $\mathrm{BDL}(\mathrm{LOD}=0.01)$ \\
\hline 13 & $\mathrm{Mg}(\mathrm{mg} / \mathrm{L})$ & 1.73 & 29 & Endosulfan $(\mu \mathrm{g} / \mathrm{L})$ & $\mathrm{BDL}(\mathrm{LOD}=0.01)$ \\
\hline 14 & $\mathrm{Na}(\mathrm{mg} / \mathrm{L})$ & 2.42 & 30 & 4,4'-DDT $(\mu \mathrm{g} / \mathrm{L})$ & $\mathrm{BDL}(\mathrm{LOD}=0.01)$ \\
\hline 15 & $\mathrm{~K}(\mathrm{mg} / \mathrm{L})$ & 2.35 & 31 & 4,4'-DDE $(\mu \mathrm{g} / \mathrm{L})$ & $\mathrm{BDL}(\mathrm{LOD}=0.01)$ \\
\hline 16 & As (mg/L) & $\mathrm{BDL}(\mathrm{LOD}=0.0005)$ & 32 & 4,4'-DDD $(\mu \mathrm{g} / \mathrm{L})$ & $\mathrm{BDL}(\mathrm{LOD}=0.01)$ \\
\hline
\end{tabular}

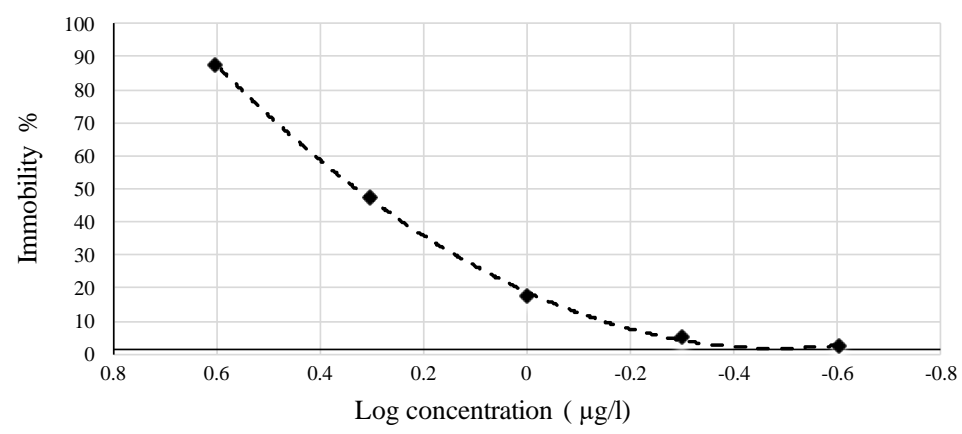

Figure 2. Daphnia concentration-immobilization rate curve. Log concentration of copper is presented in x axis, and immobility percentage of Daphnia at 48 hours is showed in y axis 


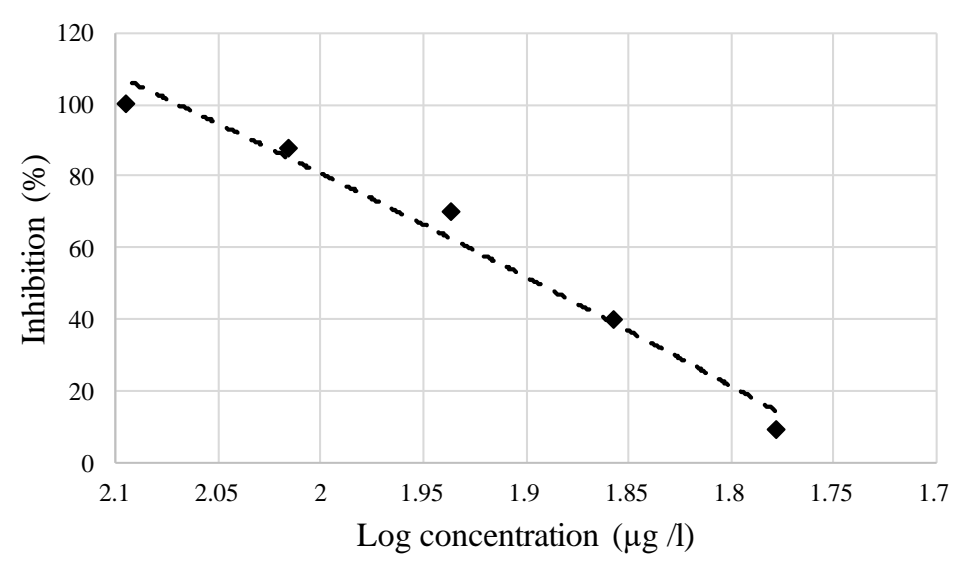

Figure 3. Algal concentration-inhibition (growth rate) curve. Log concentration of copper is presented in $\mathrm{x}$ axis, and growth rate inhibition percentage of Scenedesmus algae at 72 hours is showed in y axis

Copper is an essential micro-nutrient for living organisms by involving in varieties of protein functions, and cell respiratory. Food are the main resource for aquatic living (Bervoets \& Blust, 2003; Campbell et al., 2008). However, at high level $\mathrm{Cu}$ can be toxic by disrupting ion homeostatis, inhibiting the anhydrase enzyme in cell cytoplasma, and group of $\mathrm{Na}+, \mathrm{K}+$ -ATPases which helps to maintain osmotic equilibrium and membrane potential in cells (Giacomin et al., 2014).

Copper can be introduced into environment through electrical product wastes (Lopez et al., 2011). Due to increasing amount of this type of waste in recent year, it is the risk of $\mathrm{Cu}$ contamination of the freshwater reservoir and therefore it is required better supervision to detect $\mathrm{Cu}$ pollution in this freshwater body. For $D$. carinata, with the modified ISO test medium with pH 7.0, EC $168.8(\mu \mathrm{S} / \mathrm{Cm}), \mathrm{DO}=6.8(\mathrm{mg} / \mathrm{L})$ and temperature $29^{\circ} \mathrm{C}$, the EC50 value of $48 \mathrm{~h}$ immobilization experiment was $1.90 \mu \mathrm{g} / \mathrm{L}(95 \% \mathrm{CI}=1.58-2.33 \mu \mathrm{g} / \mathrm{L})$. The result showed that $D$. carinata in this study was more sensitive to copper than Daphnia magna with EC50 was $13 \mu \mathrm{g} / \mathrm{L}$ (Okamoto et al., 2015).

The results demonstrated that the proposed toxicity testing procedure with D. carinata is sensitive and can be considered as a potential tool for $\mathrm{Cd}$ pollution monitoring control in freshwater of Sai Gon river. The EC50 value was $1.90 \mu \mathrm{g} / \mathrm{L}$ for $\mathrm{Cu}$ make this organism a good tool for detection $\mathrm{Cu}$ pollution. According to the Vietnam's national standards (QCVN 08), the best surface water quality can have up to $100 \mu \mathrm{g} / \mathrm{L}$ of $\mathrm{Cu}$, this level was known to have no effect on human health. The study of Winner and Farrel has confirmed that members of the family Daphnidae represent some of the most acutely sensitive aquatic species to copper. In more details, they observed that all four species including D. magna, D. pulex, D. parvula, and $D$. ambigua exhibited reductions in survival at $\mathrm{Cu}$ concentrations $>40 \mu \mathrm{g} /$ liter (Winner \& Farrell, 2011). Therefore, with EC50 value $1.90 \mu \mathrm{g} / \mathrm{L}$ the proposed testing procedure using $D$. carinata is very sensitivity and easy to apply to detect copper contamination. 


\section{Macrothink}

Beside of D. carinata, freshwater microalgae Scenedesmus sp. was also use to dectect copper pollution. The combination use of different organisms could increase the reliability of heavy metal pollution detection. Using COMBO medium without EDTA prepared with water collected from the upstream of Sai Gon river. The test medium has $\mathrm{pH}=7.6, \mathrm{EC}=278(\mu \mathrm{S} / \mathrm{cm}), \mathrm{DO}=6.9$ $(\mathrm{mg} / \mathrm{L})$ and temperature $26^{\circ} \mathrm{C}$. The result pointed out the growth inhibition effect of $\mathrm{Cu}$ on the fresh water algae. The IC50 value was $78.2 \mu \mathrm{g} / \mathrm{L}(95 \% \mathrm{CI}=63.4-93.3 \mu \mathrm{g} / \mathrm{L})$ was lower than Scenedesmus subspicatus $(180 \mu \mathrm{g} / \mathrm{L})$ which has been reported previosly (Tisler \& Zagorc-Koncan, 2003). In Vietnam's national standards the allowance value of $\mathrm{Cu}$ level in A1 surface water which can be used for domestic and other purposes is $0.1 \mathrm{mg} / \mathrm{L}$ (QCVN 08). Therefore, the EC50 value of $S$. cenedesmus in this study was lower than the legal threshold of water quality. And therefore, it is a potential tool to detect $\mathrm{Cu}$ contamination water samples.

The result of this study, in consistant with previous others, confirm the high toxicity of $\mathrm{Cu}$ on fresh water algae. $\mathrm{Cu}$ contamination, lead to eliminate the population of the primary producer - algae, and then severely impact the aquatic organisms at high levels of the food chains such as microcrustacean, insect, bivalve, and fish (Wright et al., 2002).

In agreement with trigger value for copper of $1.4 \mu \mathrm{g} / \mathrm{L}$ was derived using the statistical distribution method with 95\% protection provided by of the ANZECC \& ARMCANZ (2000) guidelines (ANZECC \& ARMCANZ, 2002) the result of this study emphasized the necessary and provide a way to detect $\mathrm{Cu}$ pollution at very low level to protect the aquatic ecological environment.

\section{Conclusion}

The result showed that both two organisms are potential bioindicators for the assessment of copper pollution in Sai Gon river. However, water flea D. carinata was more sensitive than freshwater algae Scenedesmus. Beside of high sensitivity, the toxicity test procedure using two tropical aquatic organisms is also cost effective, and easy to apply. The proposed procedure in this study can be used to daily test water quality to detect the introduction of toxic pollutants such as heavy metal $\mathrm{Cu}$. In combining with the following detail chemical analysis can be combined later to precisely identify the inspect toxic pollutants, the proposed toxicity test in this study can contribute to monitoring water quality and protect human health form risks related to consuming of heavy metals contaminated waters.

\section{Acknowledgments}

This research is funded by Vietnam National University of Ho Chi Minh city (VNU-HCM) under grant number B2018-24-02 was acknowledged.

\section{Reference}

ANZECC \& ARMCANZ. (2002). Copper in freshwater and marine water. [Online] Available:

https://www.waterquality.gov.au/anz-guidelines/guideline-values/default/water-quality-toxica nts/toxicants/copper-2000

Beiramzadeh, Z., Baqersad, M., \& Aghababaei, M. (2019). Application of the response 
surface methodology (RSM) in heavy metal removal from real power plant wastewater using electrocoagulation. European Journal of Environmental and Civil Engineering, 0(0), 1-19. https://doi.org/10.1080/19648189.2019.1640139

Bervoets, L., \& Blust, R. (2003). Metal concentrations in water, sediment and gudgeon (Gobio gobio) from a pollution gradient: Relationship with fish condition factor. Environmental Pollution (Barking, Essex: 1987), 126(1), 9-19.

https://doi.org/10.1016/s0269-7491(03)00173-8

Campbell, P. G. C., Kraemer, L. D., Giguère, A., Hare, L., \& Hontela, A. (2008). Subcellular Distribution of Cadmium and Nickel in Chronically Exposed Wild Fish: Inferences Regarding Metal Detoxification Strategies and Implications for Setting Water Quality Guidelines for Dissolved Metals. Human and Ecological Risk Assessment: An International Journal, 14(2), 290-316. https://doi.org/10.1080/10807030801935009

De Schamphelaere, K. A. C., \& Janssen, C. R. (2004). Effects of chronic dietary copper exposure on growth and reproduction of Daphnia magna. Environmental Toxicology and Chemistry, 23(8), 2038-2047. https://doi.org/10.1897/03-411

Dinh Van, K., Janssen, L., Debecker, S., De Jonge, M., Lambret, P., Nilsson-Ortman, V., Beroets, L., \& Stocks, R. (2013). Susceptibility of a metal under global warming is shaped by thermal adaptation along a latitudinal gradient. Global Change Biology, 19, 2625-2633. https://doi.org/10.1111/gcb.12243

Giacomin, M., Jorge, M. B., \& Bianchini, A. (2014). Effects of copper exposure on the energy metabolism in juveniles of the marine clam Mesodesma mactroides. Aquatic Toxicology (Amsterdam, Netherlands), 152, 30-37.

https://doi.org/10.1016/j.aquatox.2014.03.025

Hoang, T. C., Tomasso, J. R., \& Klaine, S. J. (2004). Influence of water quality and age on nickel toxicity to fathead minnows (Pimephales promelas). Environmental Toxicology and Chemistry, 23(1), 86-92. https://doi.org/10.1897/03-11

Ikemoto, T., Tu, N. P. C., Okuda, N., Iwata, A., Omori, K., Tanabe, S., Tuyen, B. C., \& Takeuchi, I. (2008). Biomagnification of trace elements in the aquatic food web in the Mekong Delta, South Vietnam using stable carbon and nitrogen isotope analysis. Archives of Environmental Contamination and Toxicology, 54(3), 504-515.

https://doi.org/10.1007/s00244-007-9058-5

Jo, J, S., K, C., \& J, J. (2010). Combined effects of water quality parameters on mixture toxicity of copper and chromium toward Daphnia magna. Chemosphere, 81(10), 1301-1307. https://doi.org/10.1016/j.chemosphere.2010.08.037

Kilham, S., Kreeger, D., Lynn, S., Goulden, C., \& Herrera, L. (1998). COMBO: a defined freshwater culture medium for algae and zooplankton. Hydrobiologia, 3777, 147-159. https://doi.org/10.1023/A:1003231628456

Lanctôt, C., Wilson, S. P., Fabbro, L., Leusch, F. D. L., \& Melvin, S. D. (2016). Comparative 
sensitivity of aquatic invertebrate and vertebrate species to wastewater from an operational coal mine in central Queensland, Australia. Ecotoxicology and Environmental Safety, 129, 1-9. https://doi.org/10.1016/j.ecoenv.2016.03.003

Lau, S., Mohamed, M., Yen, A. T., \& Su'ut, S. (1998). Accumulation of heavy metals in freshwater molluscs. The Science of the Total Environment, 214, 113-121.

https://doi.org/10.1016/s0048-9697(98)00058-8

Linbo, T. L., Baldwin, D. H., McIntyre, J. K., \& Scholz, N. L. (2009). Effects of water hardness, alkalinity, and dissolved organic carbon on the toxicity of copper to the lateral line of developing fish. Environmental Toxicology and Chemistry, 28(7), 1455-1461.

https://doi.org/10.1897/08-283.1

Lopez, B. N., Man, Y. B., Zhao, Y. G., Zheng, J. S., Leung, A. O. W., Yao, J., \& Wong, M. H. (2011). Major Pollutants in Soils of Abandoned Agricultural Land Contaminated by e-Waste Activities in Hong Kong. Archives of Environmental Contamination and Toxicology, 61(1), 101-114. https://doi.org/10.1007/s00244-010-9590-6

Moldovan, O. T., Meleg, I. N., Levei, E., \& Terente, M. (2013). A simple method for assessing biotic indicators and predicting biodiversity in the hyporheic zone of a river polluted with metals. Ecological Indicators, 24, 412-420.

https://doi.org/10.1016/j.ecolind.2012.07.019

Okamoto, A., Yamamuro, M., \& Tatarazako, N. (2015). Acute toxicity of 50 metals to Daphnia magna. Journal of Applied Toxicology, 35(7), 824-830.

https://doi.org/10.1002/jat.3078

QCVN 08. National technical regulation on surface water quality. [Online] Available:

http://cem.gov.vn/storage/documents/5d6f3ecb26484qcvn-08-mt2015btnmt.pdf

Ryan, A. C., Tomasso, J. R., \& Klaine, S. J. (2009). Influence of pH, hardness, dissolved organic carbon concentration, and dissolved organic matter source on the acute toxicity of copper to Daphnia magna in soft waters: Implications for the biotic ligand model. Environmental Toxicology and Chemistry, 28(8), 1663-1670.

https://doi.org/10.1897/08-361.1

Saberi, N., Aghababaei, M., Ostovar, M., \& Mehrnahad, H. (2018). Simultaneous removal of polycyclic aromatic hydrocarbon and heavy metals from an artificial clayey soil by enhanced electrokinetic method. Journal of Environmental Management, 217, 897-905.

https://doi.org/10.1016/j.jenvman.2018.03.125

Schwarzenbach, R. P., Egli, T., Hofstetter, T. B., von Gunten, U., \& Wehrli, B. (2010). Global Water Pollution and Human Health. Annual Review of Environment and Resources, 35(1), 109-136. https://doi.org/10.1146/annurev-environ-100809-125342

Tisler, T., \& Zagorc-Koncan, J. (2003). Aquatic toxicity of selected chemicals as a basic criterion for environmental classification. Arhiv Za Higijenu Rada I Toksikologiju, 54(3), 207-213. 


\section{Macrothink}

Tomasiks, P., \& Warren, D. M. (1996). The use of Daphnia in studies of metal pollution of aquatic systems. Environmental Reviews, 4(1), 25-64. https://doi.org/10.1139/a96-003

Warnau, M., Ledent, G., Temara, A., Jangoux, M., \& Dubois, P. (1995). Experimental 20 cadmium contamination of the echinoid Paracentrotus lividus: Influence of exposure 21 mode and distribution of the metal in the organism. Marine Ecology Progress Series, 22(1666), 117-124. https://doi.org/10.3354/meps 116117

Waykar, B., \& Shinde, S. M. (2011). Assessment of the Metal Bioaccumulation in Three Species of Freshwater Bivalves. Bulletin of Environmental Contamination and Toxicology, 87(3), 267-271. https://doi.org/10.1007/s00128-011-0354-4

Wetzel, R. G. (2001). Limnology: Lake and river ecosystems. Academic Press. [Online] Available: http://site.ebrary.com/id/10606261

Winner, R., \& Farrell, M. (2011). Acute and Chronic Toxicity of Copper to Four Species of Daphnia. Journal of the Fisheries Research Board of Canada, 33, 1685-1691. https://doi.org/10.1139/f76-215

Wright, David, A., \& Pamela, W. (2002). Environmental Toxicology. Cambridge University Press. https://doi.org/10.1017/CBO9780511805998

\section{Copyright Disclaimer}

Copyright for this article is retained by the author(s), with first publication rights granted to the journal.

This is an open-access article distributed under the terms and conditions of the Creative Commons Attribution license (http://creativecommons.org/licenses/by/4.0/). 